\title{
Ten Myxomycete species new to Finland
}

\author{
MARJA HÄRKÖNEN
}

\begin{abstract}
Härkönen, M. 1981: Ten Myxomycete species new to Finland. - Karstenia 21: 53-56.

The following species of Myxomycetes are reported for the first time from Finland: Arcyria insignis Kalchbr. \& Cooke, Craterium brunneum Nann.-Brem., Cribraria aurantiaca Schrader, Cribraria macrostipitata Neubert \& Nann.-Brem., Dictydiaethalium plumbeum (Schum.) Rost., Leptoderma iridescens G. Lister, Physarum daamsii Nann.Brem., Prototrichia metallica (Berk.) Massee, Stemonitopsis hyperopta (Meylan) Nann.Brem. and Trichia erecta Rex. Five of these are also new to Fennoscandia: Arcyria insignis, Craterium brunneum, Cribraria macrostipitata, Leptoderma iridescens and Physarum daamsii.
\end{abstract}

Marja Härkönen, Department of Botany, University of Helsinki, Unioninkatu 44, SF00170 Helsinki 17. Finland

The following list contains information about 10 species of Myxomycetes, new to Finland. The material examined is deposited in the Finnish herbaria $\mathrm{H}$ and OULU, and the short description of each species is based on my own observations and measurements of the listed specimens. If not otherwise mentioned, the notes on the general distribution are based on Emoto (1977), Farr (1976), Guarrera et al. (1975), Lakhanpal \& Mukerji (1981) and Martin \& Alexopoulos (1969), and earlier Scandinavian records on Bjørnekaer \& Klinge (1963), Blytt (1892), Eliasson (1975), Eliasson \& Lundqvist (1979), Eliasson \& Strid (1976), Eliasson \& Sunhede (1972), Härkönen (1979b), Karlsen (1934, 1943), Lister (1911) and Santesson (1964). The colour code numbers refer to Maerz \& Paul (1950). The publication of the description is cited only for species described after Martin \& Alexopoulos (1969).

\section{Arcyria insignis Kalchbr. \& Cooke}

V: Karjalohja, Karkali, Corylus avellana stand, on litter, IX 1979 Leino (H). Cosmopolitan, but common only in tropical regions (see e.g. Robrecht 1974, Nannenega-Bremekamp 1974 and Härkönen 1981). - Not reported earlier from Fennoscandia.

Sporangia in small clusters, cylindrical, $1.5-2 \mathrm{~mm}$ tall, $0.3 \mathrm{~mm}$ in diam, rose-coloured (4 D 9 'Polignac'). Stipe short, filled with spore-like cells. Cup shallow, thin, furrowed. Capillitium a net of delicate threads ( $2 \mu \mathrm{m}$ in diam.), which are yellowish in transmitted light, have (up to $1 \mu \mathrm{m}$ ) sharp spines and half rings, arranged in loose spirals. Spores hyaline, smooth with some scattered inconspicuous warts, $7-7.6-8$ $\mu \mathrm{m}$ in diam.
Craterium brunneum Nann.-Brem., Proc. K. Nederl. Akad. Wetenschappen (C) 76: 481. 1973.

EK. Vehkalahti, Pyhältö, bark of decaying branch of Pinus sylvestris, VI 1979 Fagerström $(\mathrm{H})$. - Reported only from the Netherlands.

Sporangia gregarious, $0.8-1.3 \mathrm{~mm}$ tall, $0.3-0.8$ $\mathrm{mm}$ in diam, glossy brown throughout. Hypothallus well developed, discoid. Stalk about half the total height, dark brown, furrowed. The head of the sporangium goblet-shaped and having a ring, on which rests a discoid lid, somewhat sunk in the sporangium. Peridium thick, enclosing some granular material and apparently consisting of a single layer (but according to the description (Nannenga-Bremekamp 1973) composed of two closely applied layers). Capillitium weakly developed, having small brownish lime nodes. Spores dark brown in mass, violaceous brown in transmitted light, densely and very minutely spinulose $8.5-9.4-9.5 \mu \mathrm{m}$ in diam.

The specimen also resembles the picture of Craterium concinnum Rex in Emoto (1977), but according to Martin \& Alexopoulos (1969) that species has 'a pale operculum, which contrasts strongly with the darker cup'.

\section{Cribraria aurantiaca Schrader}

U: Kemiö, Wijksgård, on Hymenochaete rubiginosa on old stump of oak, IX 1979 Ulvinen (OULU). - Widely distributed, but confusion with $C$. vulgaris makes the distribution data unreliable.

Sporangia gregarious, stalked, globose $1.2-1.5$ $\mathrm{mm}$ high, $0.4-0.5 \mathrm{~mm}$ in diam, bright yellow $(11 \mathrm{~K} 7$, Buff), stalk dark, furrowed. Hypothallus small, dark 
brown. Cup well developed, about $1 / 3$ of sporangium, with delicate stration consisting of bands of granules. Connections between cup and net numerous and relatively long. The net small-meshed, the nodes numerous, dark, rounded and without free ends. Spores in transmitted light nearly colourless, in immersion oil barely seen to be spinulose and having occasional refractive inclusions, $6-6.5 \mu \mathrm{m}$ in diam.

All the earlier specimens in Finnish herbaria referred to the group $C$. vulgaris $-C$. aurantiaca have been determined as $C$. vulgaris (Härkönen 1979a) according to the description of Nannenga-Bremekamp (1964).

Cribraria macrostipitata Neubert \& Nann.-Brem., Zeitschr. f. Pilzkunde 43: 238. 1977. — Figs. 3-4 V: Kemiö, Kuggböle, on coniferous decayed wood in moist chamber, XII 1979 and III 1980 Wikström 5192 and 5197 (H). - Known only from the type locality on the Andes of Venezuela.

Sporangia gregarious, dark reddish brown, glossy (excluding the spore mass). Total height $1-1.7 \mathrm{~mm}$, the head of the sporangium globose, $0.15-0.3 \mathrm{~mm}$ in diam. Hypothallus discoid. Stalk slender, furrowed. Cup about $1 / 6-1 / 3$ of sporangium, ribbed and toothed in the margin. The net rather wide-meshed and lax, nodes thickened and having several connected and also some free ends (see Figs. 3-4). Dictydine granules about $1.5 \mu \mathrm{m}$. Spores ochraceous in mass, light yellow, nearly colourless in transmitted light, very minutely and densely spinulose with occasional brilliantly refractive inclusions, $7-7.6-8.5 \mu \mathrm{m}$ in diam.

One of the authors of this species, Mrs NannengaBremekamp, has determined one of the specimens and considers it a beautiful representative of the newly described species, in spite of the distance from the type locality and the fact that the sporangia are somewhat smaller than those in the description. As may be seen in Figs. 3 and 4, the general appearance and the peridial net do look exactly the same as in the drawings belonging to the description (Neubert \& Nannenga-Bremekamp 1977).

\section{Dictydiaethalium plumbeum (Schum.) Rost.}

U: Helsinki, Munkkivuori, on stump of Sambucus racemosa, XI 1979 Karttunen $139(\mathrm{H})$. - Cosmopolitan, known from all the Scandinavian countries.

Pseudoaethalia brown (15 E 9), flat-pulvinate, $2-20 \mathrm{~mm}$ in diam, resembling aethalia. They are composed of closely compacted sporangia about 0.2 $\mathrm{mm}$ in diam. Hypothallus silky white. Rigid, undivided pseudocapillitium hangs from 5 to 6 corners of the sporangia caps. Spores ochraceous brown in mass, pale yellow in transmitted light, minutely war- ted and having a lighter germ pore, $7.8-8-8.6 \mu \mathrm{m}$ in diam.

Leptoderma iridescens G. Lister

- Fig. 2

KP: Vimpeli, Lakaniemi, wood of Betula alba, X 1978 Harmaja $(\mathrm{H})$. - Evidently rare. Known from Europe, North America and also from India. Not reported earlier from Fennoscandia.

Sessile, pulvinate sporangia partially merging together into short plasmodiocarps, $0.5-0.9 \mathrm{~mm}$ in diam. Peridium membranous, wrinkled, grey (46 A 6, Cadet), weakly iridescent, yellowish in transmitted light and enclosing granular material. No columella. Capillitium radiating from base of sporangium; stout, dark brown in the middle, colourless in extremities and having dark or colourless expansions and also some fusiform swellings enclosing granular material (Fig. 2). Spores dark brown in mass and also fairly dark in transmitted light, coarsely and irregularly warted, $10-11.6-12.5 \mu \mathrm{m}$ in diam.

Physarum daamsii Nann.-Brem., K.Ned. Akad. Wetenschappen C 74: 363. 1971.

EnL: Kilpisjärvi, Biol. Station, on litter and living plants, VIII 1979 Harmaja (H). - Known earlier only from the type collection (the Netherlands).

Sporangia sessile, crowded on top of each other in small clusters, subglobose, $0.2-0.4 \mathrm{~mm}$ in diam (resembling those of $P$. virescens or $P$. confertum except in colour). Peridium rugose and encrusted with lime, light bluish grey (45 A 5). Hypothallus inconspicuous. No columella. Capillitium with many pure white fairly large and angular lime knots. Spores dark brown in mass and also fairly dark in transmitted light, very finely warted, $7.8-9.7-11.5 \mu \mathrm{m}$ in diam.

Prototrichia metallica (Berk.) Massee

- Fig. 1

EK: Vehkalahti, Pyhältö, decayed wood, VI 1979 Fagerström (H). - Distributed in North America, Europe and Tasmania. Reported from Norway and Sweden.

Sporangia gregarious, sessile, $0.5-1.3 \mathrm{~mm}$ in diam, olive brown to olive yellow (14 A-L 9-12). Peridium membranous, thin, transparent, iridescent. Capillitium consisting of stiff, pinkish yellow, spirally interwound threads, which are partially fused together, but at the extremities separate into 3-10 strands (Fig. 1). Spores olive yellow in mass, light yellow in transmitted light, minutely and densely spiny, $11-11.5-13.5 \mu \mathrm{m}$ in diam.

\section{Stemonitopsis hyperopta (Meylan) Nann.-Brem.}

EK: Vehkalahti, Pyhältö, on decayed log, VIII 1979 Fagerström (H). St: Ikaalinen, virgin forest Multiharju, fallen trunk of Pinus sylvestris, VII 1979 Härkönen (H). - Widely distributed (North America, Sout America, Europe, Japan, India). Reported from Denmark and Sweden. 

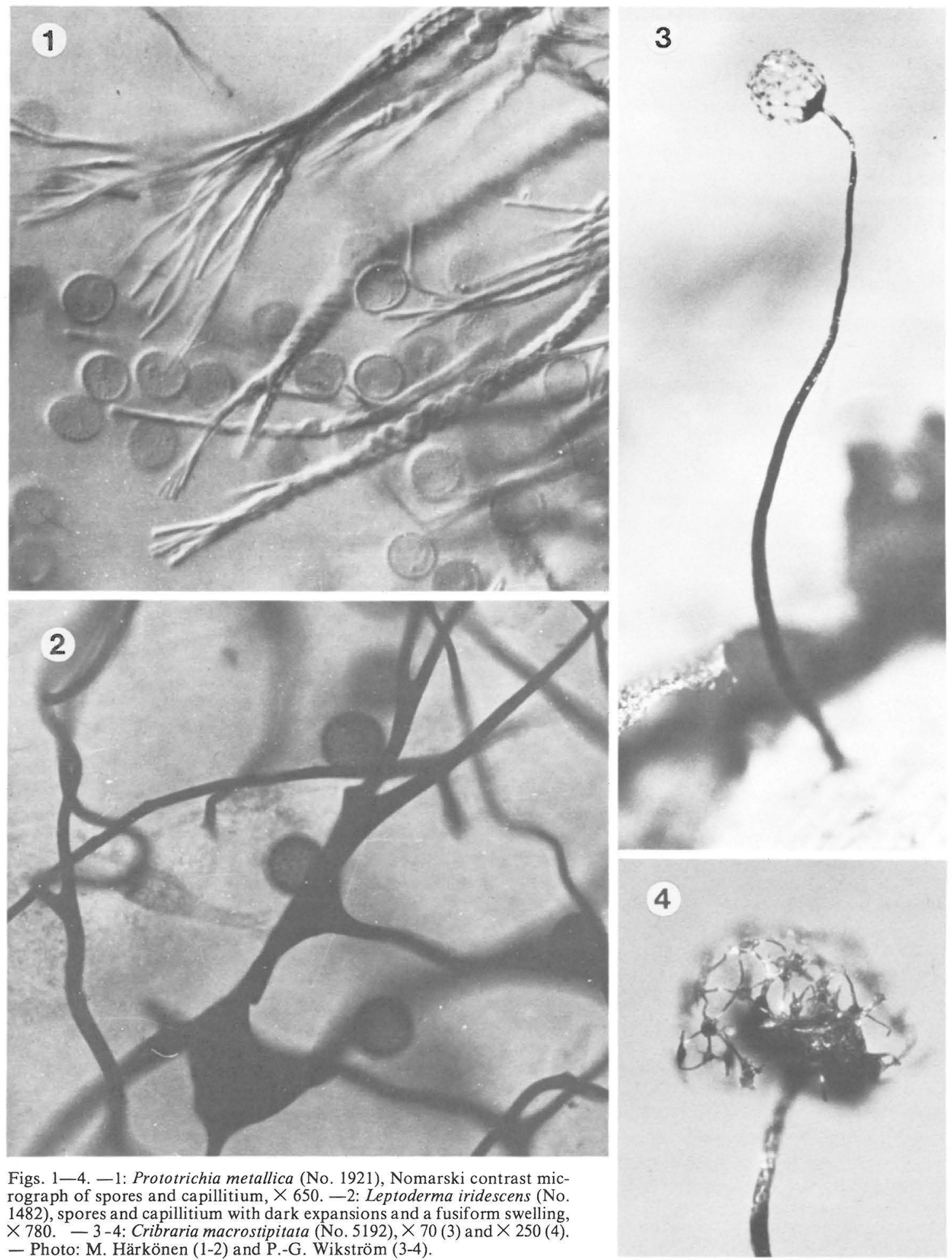

Figs. 1-4. -1: Prototrichia metallica (No. 1921), Nomarski contrast micrograph of spores and capillitium, $\times 650 .-2$ : Leptoderma iridescens (No 1482), spores and capillitium with dark expansions and a fusiform swelling, $\times 780$. - 3-4: Cribraria macrostipitata (No. 5192), $\times 70$ (3) and $\times 250$ (4). - Photo: M. Härkönen (1-2) and P.-G. Wikström (3-4). 
Sporangia in small clusters, cylindrical, $2.5-3 \mathrm{~mm}$ high, $0.4-0.5 \mathrm{~mm}$ in diam, lilac brown $(8 \mathrm{C} 4$, London smoke). Hypothallus inconspicuous. Stalk black, about $1 / 3$ of total height. No trace of peridium. Capillitium abundant, flexuous, brown, forming a surface net only on lower part of the sporangium. Spores lilac brown in mass, nearly colourless in transmitted light, having some small meshes, connected by a very delicate reticulation of bands $5-6.2-6.5 \mu \mathrm{m}$ in diam.

\section{Trichia erecta Rex}

EK: Vehkalahti, Pyhältö, decaying branch, V 1980 Fagerström (H). - Distributed in North America, Europe, Ceylon and Japan. Reported from Sweden.

Sporangia gregarious, stalked, club-shaped, partly occurring in twos. Total height $1-1.2 \mathrm{~mm}$, diam. $0.8-1 \mathrm{~mm}$. Hypothallus small, dark brown. Stalk stout, furrowed, opaque, dark brown, about $0.3-0.5$ $\mathrm{mm}$ in height. Peridium thick, dark brown with narrow dull yellow, thin bands resembling that in $T$. botrytis. Capillitium consisting of bright yellow, relatively short, twisted, branched elaters with short-tapering ends. Spores yellow, minutely warted, $10.5-12-14 \mu \mathrm{m}$ in diam.

Acknowledgements. I want to thank Mrs N. E. NannengaBremekamp for looking at and discussing (in litt.) all the specimens reported here, and Mr P.G. Wikström for the photographs of Cribraria macrostipitata.

\section{References}

Bjørnekaer, K. \& Klinge, A. 1963: Die dänischen Schleimpilze. Myxomycetes Daniae. - Friesia 7: 149-196.

Blytt, A. 1892: Bidrag til kundskaben om Norges soparter 3. Myxomyceter. - Videnskabs-Selskabs Forhandl., Christiania, 1892 (2): $1-13$

Eliasson, U. 1975: Myxomycetes in the nature reserve of the
Gothenburg Botanical Garden. - Svensk Bot. Tidskr. 69: $105-112$.

Eliasson, U. \& Lundqvist, N. 1979: Fimicolous myxomycetes. - Bot. Notiser 132: $551-568$.

Eliasson, U. \& Strid, A. 1976: Wood-inhabiting fungi of alder forests in North-Central Scandinavia 3. Myxomycetes. - Bot. Notiser 129: 267-272.

Eliasson, U. \& Sunhede, S. 1972: Some Swedish records of myxomycetes. - Svensk Bot. Tidskr. 66: 18-24.

Emoto, Y. 1977: The Myxomycetes of Japan. - 263 pp. Tokyo.

Farr, M. 1976: Myxomycetes. - Flora Neotropica Monogr. 16: 1-304. New York.

Guarrera, S., Gamundi de Amos, I., Rabinovich de Halperin, D. 1975: Division Myxophyta, clase Myxomycetes. Flora criptogámica de Tierra del Fuego 2: 1-107. Buenos Aires.

Härkönen, M. 1979a: Additions and corrections to the Finnish flora of Myxomycytes. - Karstenia 19: 1-7.

- 1979b: A check-list of Finnish myxomycetes. - Karstenia 19: $8-18$.

- 1981: Gambian Myxomycetes developed in moist chamber cultures. - Karstenia 21: $21-25$.

Karlsen, A. 1934: Studies on myxomycetes 1. New records for Norway. - Bergens Mus. Arbok, Naturvidensk. Rekke 1: 1-8.

- 1943: Studies on Myxomycetes 2. The Myxomycetflora of Hardanger. - Bergens Mus. Ârbok, Naturvidensk. Rekke 4: 1-34.

Lakhanpal, T. \& Mukerji, K. 1981: Taxonomy of the Indian Myxomycetes. - Bibliotheca Mycologica 78: 1 -530. Vaduz.

Lister, A. 1911: A monograph of the Mycetozoa. 2nd ed., revised by G. Lister. - 302 pp., 200 pls. London.

Maerz, A. \& Paul, M. 1950: Dictionary of color. 2nd ed. 208 pp. New York.

Martin, G. \& Alexopoulos, C. 1969: The Myxomycetes. $560 \mathrm{pp}$. Iowa City.

Nannenga-Bremekamp, N. 1964: Notes on Myxomycetes 7. - Acta Bot. Neerl. 13: 113-147.

- 1971: Notes on Myxomycetes 17. Some new species in Cribraria, Comatricha and Physarum, a new variety in Macbrideola and new name in Arcyria. - Proc. K. Nederl. Akad. Wetenschappen (C) 74: 352-265.

- 1973: Notes on Myxomycetes 19. - Proc. K. Nederl. Akad. Wetenschappen (C) 76: 476-488.

- 1974: De nederlandse myxomyceten. -440 pp. Zutphen.

Neubert, H. \& Nannenga-Bremekamp, N. 1977: Drei neue Arten aus der Klasse Myxomycetes. - Z. Pilzkunde 43: $237-242$.

Robrecht, E. 1974: The genus Arcyria Wiggers (Myxomycetes) in Belgium. - Bull. Jard. Bot. Nat. Belgique 44: $303-353$.

Santesson, R. 1964: Swedish Myxomycetes. - Svensk Bot. Tidskr. 58: 113-124.

Accepted for publication

on June 16,1981 